\title{
Have World Historical Events Influenced the History of Phytotherapy?
}

\author{
André-Michael Beer* and Birke Müller \\ Direktor der Klinik für Naturheilkunde, Ruhr-Universität Bochum, Germany \\ *Corresponding author: André-Michael Beer, Direktor der Klinik für Naturheilkunde, Klinik Blankenstein, Hattingen, Lehrbereich \\ Naturheilkunde, Ruhr-Universität Bochum, Im Vogelsang 5-11, 45527 Hattingen, Germany \\ To Cite This Article: André-Michael Beer, Birke Müller, Have World Historical Events Influenced the History of Phytotherapy?. Am J Biomed Sci \\ \& Res. 2021 - 12(1). AJBSR.MS.ID.001713. DOI: 10.34297/AJBSR.2021.12.001713.
}

Received: 眥 February 10, 2021; Published: 笽 February 22, 2021

\begin{abstract}
Background: A synchronoptic display is intended to illustrate the extent to which events in world history have influenced the development of phytotherapy.

Methodology: The upper part of the exhibit shows the central historical events. The lower part shows the history of naturopathy and the middle part the history of phytotherapy.

Results: The synchronoptic representation made it possible to identify two periods, "historical gaps", in which the development of phytotherapy stagnated due to world history: 1st gap: 14th century, 2nd gap: c. 1640 - c. 1800.

Discussion: The reasons for the 1st gap were the process of deserted Medieval villages and the plague epidemic and for the 2nd gap, the Little Ice Age, the Thirty Years' War and a lack of convincing theory about medical healing.

Summary: Medicinal plants are among the oldest remedies and were used according to the principle of "trial and error". What proved successful was passed on, and otherwise, discarded. What is often forgotten here is that certain events in world history and also in the naturopathic movement have had a decisive influence on the development of phytotherapy. The synchronoptic representation of the exhibit has now made it possible for the first time to identify "historical gaps" where phytotherapy development stagnated.
\end{abstract}

Keywords: History, Phytotherapy, Synchronoptical representation, Historical gaps, Development

\section{Introduction}

It is important to establish to what extent events in world history have had an influence on the development of phytotherapy. This is better illustrated by means of a synchronoptic representation. We have borrowed spiritually from Unschuld [1]. In his book Was ist Medizin? (What is Medicine?), he postulates that medical thinking in the West and East is closely linked to people's social and economic living conditions and lifestyles. By means of the synchronoptic representation Figure 1, two periods can be identified in which the development of phytotherapy stagnated for reasons of world history. These historical gaps can be traced back to different, drastic processes in world history or changes in the view of healing in medicine.

\section{Middle ages (800-1500)}

The history of phytotherapy can hardly be separated from the history of medicine in terms of content. In antiquity and the Middle Ages, about $80 \%$ of remedies were predominantly of purely herbal origin, the remaining $20 \%$ were of animal and mineral origin [2]. In the Middle Ages, the monasteries were the centre of medical culture. The monks not only cultivated the medicinal plants in the monastery gardens and treated patients with them but also preserved old manuscripts and traditions about medicinal plants and made further copies [3].

"Macer floridus", "Liber graduum" and Circa instans", it was above all the writings of the abbess Hildegard von Bingen (1098- 
1179) that found wider circulation in the middle of the 12 th century.

In addition to monastery gardens, medicinal plants were also cultivated in royal gardens and the gardens of medical schools in the early Middle Ages. The choice of plants was guided by a decree of Charlemagne (747-814). He specified in his crown estates decree [4] "capitulare de villis" exactly which types of plants (fruit trees, vegetables, spices and medicinal plants) were to be cultivated on his crown estates. This decree can be dated as the official beginning of Western European phytotherapy. Accordingly, the timeline of the exhibit begins with this dating (figure 2). A group of healers, the civitas salernitatis, in the Italian port city of Salerno, founded the first medical school (995-1087), in which an independent occidental medicine was developed in the 11th century. The medical school in Salerno also flourished due to the crusader ships that docked here (Crusades from 1095 to the 13th century), whose sick required treatment. In addition to treating the sick, early medieval healers revised traditional writings and produced medical manuals and books on pharmacology. Plants were considered the most important raw materials for the production of medicines and the urban apothecary gardens were modelled on the monastery gardens.

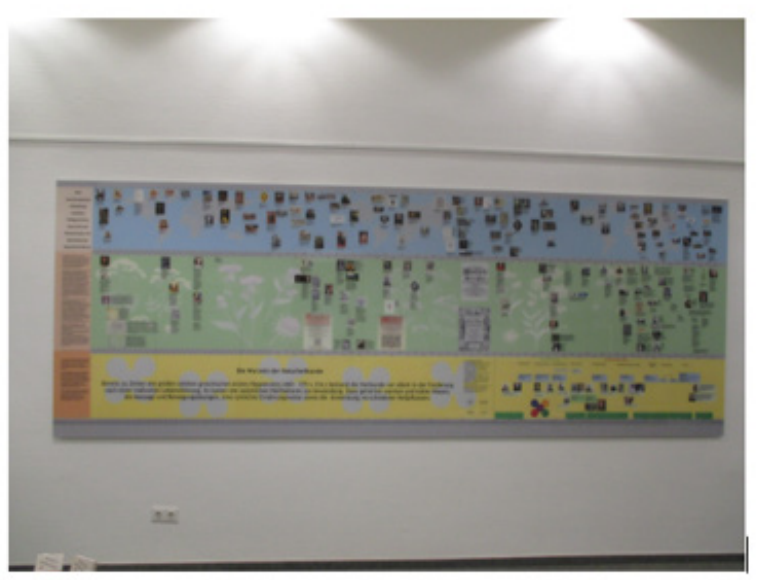

Figure 1: Overview of the synchronoptic representation.

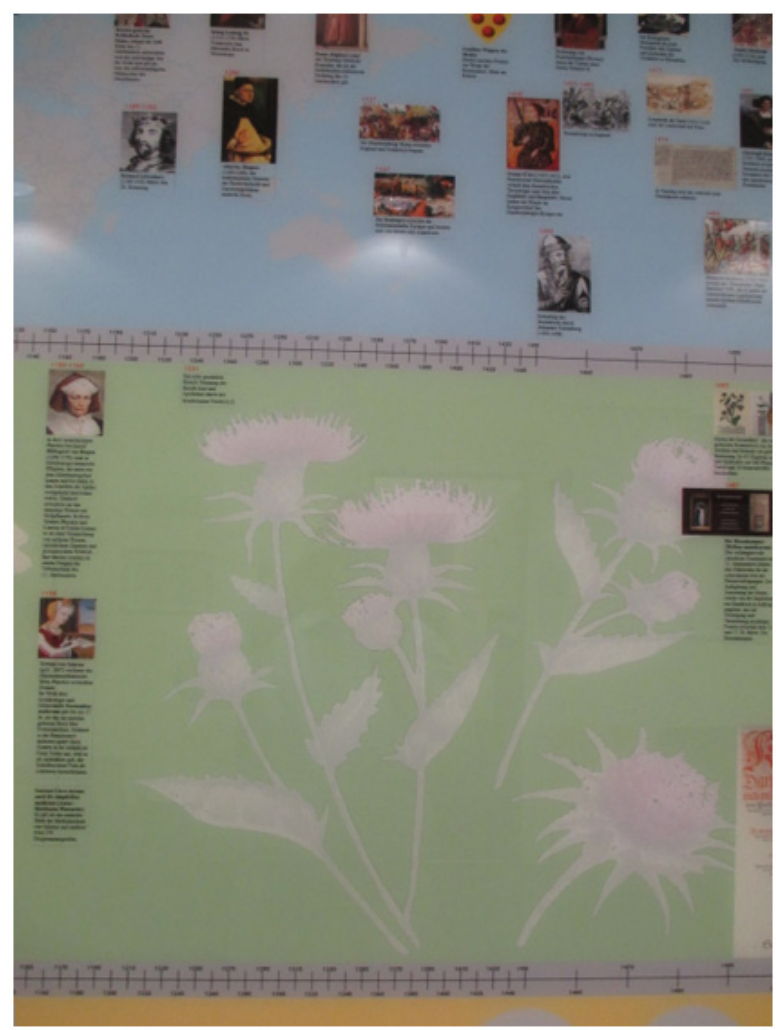

Figure 2: Detail from the exhibit: Early Middle Ages, when dating of the representation starts. 
The year 1231 was an important historical moment in the history of European herbal medicine. The Holy Roman Emperor Frederick II (1194-1250) issued a medical edict for his kingdom of Sicily, in which the separation of the two healing professions of doctor and pharmacist was legally established for the first time.

The 1st gap in the development of phytotherapy occurred in the 14th century. The main causes were the process of deserted Medieval villages and plague epidemics (1300-1400).

\section{Processes of deserted medieval villages}

So-called processes of deserted Medieval villages occurred in Europe from the 14th century onwards (c. 1310). Deserted is the term for a settlement or economic area that has been abandoned but which is still evidenced by documents or oral traditions. There was a population decline in the countryside due mainly to a restructuring of rural social and economic systems and as a consequence of the increasing founding of towns in the 13th century, but also due to crop failures, wars and the plague epidemic. As a result, a large number of monasteries and the lower nobility could no longer exist in the customary form. One reason for this was the lack of tithes, so that other means of subsistence had to be sought. The spiritual work in the monasteries could, therefore, not be continued in the usual form. There were radical methods of exploitation of the remaining rural population or, popular with the nobility, raids. The severe economic hardship and social misery of the "dependent population" led to frequent regional uprisings, which finally culminated in the peasant revolts (Great Peasants' War) of 1524/1525.

During this time, an increasing number of hospices were founded in the towns and cities by the rich bourgeoisie, which took in those people who had become social cases due to their migration from the countryside. Charitable works were performed there: feeding, sheltering and clothing the poor, and caring for and treating the sick and elderly. In addition, the orders of the Friars Minor (Franciscans, Capuchins, etc.) were increasingly established in order to care for the rural population stranded in the cities. However, this did not lead to a further development of phytotherapy.

\section{Plague epidemic}

The plague epidemics (beginning in 1348/49) caused a further upheaval in the middle of the 14th century. The Middle Ages had not known a major epidemic before and the medical profession could only explain the rapid spread of the disease, which initially mainly affected the port cities, by an effect of the planets or by "harmful vapours" according to the miasma doctrine [5]. At that time, penitential practices, masses, and processions to propitiate God, bloodletting, burning of aromatic substances and surgical opening of plague sores were used as remedies. People did not yet know that with every unloaded shipload of grain, rats also came off the ship, bringing the plague with their parasites, the rat fleas, into the densely populated city, which was believed to be safe. Consequently, the Hanseatic League's maritime cities were the first to be affected. From there, the plague spread about $30 \mathrm{~km}$ per day-the travelling speed of the time. In the course of the plague epidemics, an estimated third of the current population died, about 25 million people. This also gave astrology a greater influence on medicine in the late Middle Ages. Corresponding writings on the subject had already existed since antiquity, but they played hardly any role in the theory and practice of the early and high Middle Ages. It is not found at all in the main works from Salerno.

\section{Renaissance and european expansion in the early modern period (1400-1600)}

Two world events in the 15th century contributed significantly to the spread of phytotherapy: on the one hand, the development of the printing press and, on the other hand, the discovery of America. Many exotic plants were imported to Europe and books on medicinal plants were printed and distributed. An excellent example is Frank Konrad von Megenberg (1309-1374), rector of the Vienna Cathedral School, then canon in Regensburg. He created the first German encyclopaedia of nature, written in two different versions between 1348 and 1358, using the Liber de natura rerum by Thomas Cantimpratensis (1201-1270) as one of his sources. As another source, he used the Circa instans, a key work of the medical school of Salerno mentioned above. He also referred to Albertus Magnus (1200-1280), who produced the first detailed account of Central European flora and fauna. A total of 89 herbs are presented in his book 5. It became very important and widespread and was reprinted as a nature book in Frankfurt in 1536 and 1540. The greatest encyclopaedic work of the epoch is the Speculum maius by the Dominican Vincent of Beauvais (c. 1190-1264). The entire encyclopaedia went into print in 1474. Vincent of Beauvais strove to incorporate all the material available into his pharmacologicalbotanical sections. His sources were not only the Circa instants but also works by Pliny, Dioscorides, Avicenna and Constantinus Africanus.

The herbalists also took advantage of the opportunities opened up by the art of printing and, thus, contributed significantly to the spread of botany after two rather meagre centuries of science. The doctors and botanists Hieronymus Bock (1498-1554), Otto Brunfels (1488-1534) and Leonhart Fuchs (1501-1566) are particularly worthy of mention as the "fathers of botany" [2]. The work of the physician and natural scientist Paracelsus (1493-1541) is of great importance for the development of pharmaceutical analysis and drug production during this time. Consequently, the basis for the scientific botanical system was created, which was only continued in the 18th century by Carl von Linné (1707-1778) and elaborated into the botanical classification valid today. A 2 nd gap formation can 
be seen on the synchronoptic representation between 1640 and c 1800. The Little Ice Age, the Thirty Years' War and the development of different medical theories could essentially be identified as the causes for this.

\section{The Little ice age (1400-1850)}

Climatic changes occurred during the "Little Ice Age" (14001850 ) that led to different cool phases both regionally and temporally. The periods of global cold in the northern hemisphere were 1570-1630 and 1675-1715. During these periods, very cold, prolonged winters and cool, rainy summers frequently occurred. Winters of starvation due to destroyed harvests characterized the period. Floods were also particularly serious, affecting mainly the settlements and towns in floodplains. The transport routes of the time in northern Europe - channels and canals - froze over in winter. This created a catastrophic situation for the people, which manifested itself in despair, mistrust and a doomsday mood. These grievances prepared the ground for an upheaval in society and - among other circumstances - are considered a breeding ground for the wars in the first half of the 17th century, such as the Thirty Years' War.

\section{Thirty years' war (1618-1648)}

It can be assumed that about $40 \%$ of the rural population overall lost their lives during the war. In addition to the direct atrocities of the war, hunger and epidemics were primarily responsible for the mass deaths. The loss of people in the cities is estimated to have been somewhat lower, probably between 20 and $30 \%$. If one assumes the total population of the empire in 1618 of about 18 million people and a total of about a third lost their lives directly or indirectly, one can assume that 6 million victims died in the war. With few exceptions, the empire was hit by a severe economic decline after 1648. The farmers' livestock were almost completely destroyed in large parts of the empire, which made a quick recovery of the situation almost impossible. Many farmers were even forced by this hardship to cede their property to the nobility and, thus, fell into a great state of dependency.

\section{Development of different medical theories}

From antiquity until the 19th century, medicine was treated according to the humoral pathology of Hippocrates. At the end of the 18th century until the beginning of the 19th century, different theories concerning the causes of illness and the possibilities of healing emerged, such as Brownianism (according to John Brown), homeopathy, theosophy/anthroposophy and - in Germany romantic natural philosophy, which also had a brief influence on medicine. This includes the relationship between naturopathy and phytotherapy. The London physician Thomas Sydenham (1624-1689) and his Dutch successor Herman Boerhaave (1668-
1738) were concerned with renewing and perfecting Hippocratic principles in the art of healing. They assumed above all the so-called "self-healing power" of the body. The natural healing factors were used. These included warm and cold water, massage, movement exercises and a simple diet.

The highest commandment was, therefore, unconditional trust in the wisdom of nature. What remained for the doctor was to support nature in her work. Theodor Hahn said: "A doctor must always be the willing and obedient servant of nature." Accordingly, the naturopaths, mostly energetic lay healers, radically rejected any form of medicinal therapy [6,7]. The word "medicine", according to J. H. Rausse, was "synonymous with the term poison". As a consequence, naturopathy had to remain a strictly drugless art of healing. All medicines were considered poisons without distinction. This applied both to the chemical substances of established orthodox medicine and to healing tinctures or homeopathic concoctions. The latter could not, therefore, be counted among the natural healing methods. Frank Schönenberger, in his inaugural lecture as the first professor of naturopathy at Berlin University in 1920, explicitly referred to this "first and most noble law of naturopathy". He made it clear: "What keeps the body healthy must also be able to heal it." Basically, therefore, there were no remedies, only food. However, Ernst Schweninger, Bismarck's personal physician, also held this position. Even in the Dresden Model (1934-1943), a joint internal medicine-naturopathic hospital ward of Alfred Brauchle and Louis Grote, Brauchle is said to have repeatedly questioned the necessity of medicines. However, due to the development of penicillin and of sulphonamides, even Alfred Brauchle could no longer invoke the naturopathic idea as a drugless art, especially in times of war. While in the Third Reich, the project of the "New German Healing" accelerated the demise of the old naturopathy, phytotherapy received a boost. Until 1933, herbal medicine had not played a significant role in the naturopathic movement for the reasons mentioned above.

\section{$19^{\text {th }}$ Century}

A significant event was the isolation of morphine from opium, the dried latex of the unripe fruit of the opium poppy, in 1805 by the pharmacist Friedrich Wilhelm Adam Sertürner (1783-1841). He had discovered with morphine the first representative of a new basic class of active substances, the alkaloids. Until then, active herbal ingredients had only been known as acids. In the following years, ingredients of medicinal plants known already were increasingly isolated, which were then accessible as pure substances for further chemical and pharmacological investigations. The French doctor Henri Leclerc (1870-1955) finally coined the term phytotherapy in the 20th century. This officially established herbal medicine as a science in its own right, dealing with the application of herbal remedies to sick people. 


\section{Imperialism and world wars in the $20^{\text {th }}$ Century}

\section{The First world war}

The position of phytotherapy changed with Germany's entry into the First World War. The fighting cut the German people off from essential imports that were necessary for the production of medicines. The authorities ordered an increased use of indigenous medicinal plants. In 1915, the Prussian Ministry of the Interior instructed the Pharmacists' Association to promote the collection of medicinal herbs.

\section{The National socialist Era, second world war}

The rise to power of the National Socialists brought about a further increase in state support for herbal medicine. Phytotherapy accommodated the efforts of biological medicine to achieve the greatest possible variety of procedures. It was again a matter of securing the supply of medicines in view of the impending outbreak of war. In 1935, Gerhard Wagner, the Reich's Doctors' Leader, founded the Reich Working Group for "Medicinal Plants and Medicinal Plant Procurement". It was headed by Gottfried Schmierer, the Reich's Chief Pharmacist. The official mission of the working group was to make the import of foreign raw materials superfluous through the production of domestic medicinal herbs. In 1937, the Reich Working Group agreed with the Reichsführer of the SS, Heinrich Himmler, on forced labour in concentration camps for plant cultivation. The Dachau medicinal herb plantation in particular developed into the core of a profitable business enterprise. Thus, numerous medicinal plants were cultivated by prisoners in the concentration camps to supply the army. Walther Ripperger, pharmacist of the Reich Working Group for "Medicinal Plants and Medicinal Plant Procurement", noted with satisfaction in 1939 that the change in thinking about medicinal plants had only been properly recognised and promoted in the Third Reich [7].

In the post-war period, the immense damage caused by the war had to be repaired in Europe. There was hunger, a dearth of all kinds of goods and a housing shortage. Millions of displaced people moved through Europe in search of old or new homes. During this time, it was a matter of rebuilding state order, a new economic structure and infrastructure.

\section{Post-war period}

There were ground-breaking developments in medicine after the Second World War, such as the widespread use of antibiotics (penicillin, streptomycin) and the development of vaccines, local anaesthetics and psychopharmaceuticals. Parallel to this, the development of phytotherapy was also advanced. Rudolf Fritz Weiss (1895-1991), the founder of the "Gesellschaft für Phytotherapie" (Society for Phytotherapy) and head of the "Phytotherapy" working group at the Zentralverband der Ärzte für Naturheilverfahren und
Regulation smedizin e.V. (ZAEN: Central Association of Doctor of Naturopathy and Regulatory Medicine), made therapy with medicinal plants his subject after the war [8]. There has been an increasing renaissance of herbal medicines since the $1980 \mathrm{~s}$. Experiential knowledge that has been preserved and passed down over centuries has been verified with scientific methods. Today, phytotherapy combines traditional folk medicine with the scientifically proven findings of modern medicine as never before in history [9].

\section{The Modern era}

Nowadays, classical naturopathic treatments are firmly anchored in orthodox medicine. Phototherapeutics are often prescribed, especially in the field of registered doctors-mostly due to patient demand [10]. Phototherapeutic treatment alternatives are also mentioned in the guidelines. In addition, there are seven clinics in Germany where naturopathy and phytotherapy are used in an inpatient setting. This enables a pluralistic healthcare system in which homeopathic, anthroposophic and herbal medicines are on the market which are laid down in the Medicines Act, one of the strictest laws we have in Germany.

\section{Outlook}

The situation regarding phytotherapy has changed increasingly in recent years. In order to keep the statutory health insurance stable in terms of contributions, health reforms were carried out several times during the years from 1973 to 2015. In this context, the "GKV-Modernisierungsgesetz" (Statutory Health Insurance Modernisation Act) in 2004 and the "ArzneimittelRichtlinie" (Medicines Guideline) in 2008/09 severely restricted the reimbursement of phytopharmaceuticals by the statutory health insurance, with four exceptions. As a result, the number of authorised phytotherapeutics has decreased for several reasons. On the one hand, new registrations have become rare, mainly because of the immense costs for the studies on quality, efficacy and safety required, which ultimately make the medicine unprofitable. On the other hand, many manufacturers have refrained from reapproving or registering their phytopharmaceuticals according to Directive 2004/24/EC and sell them as healthcare preparations or food supplements, which are not subject to the Medicinal Products Act but to the Foodstuffs Act. In 1995, the Red List still listed about 960 phytopharmaceuticals, whereas in 2013, there were only 441 [11].

In accordance with the further education guidelines of 2020, the proportion of teaching hours on phytotherapy was reduced from 38 to 20 hours in the supplementary qualification "Naturopathic Medicine" [12]. In addition, due to the current Sars-CoV-2 pandemic, the advanced training "Phytotherapy" can presently no longer be offered [13]. These are more recent examples of how developments can be curtailed by historical world events. Whether this will 
develop into a long-lasting stagnation in the sense of a "third gap" remains to be seen.

\section{Acknowledgements}

We would like to thank Dr Gabriele Isenberg, historian and medieval archaeologist, and Mr Johannes Mayer (2019†), research group on monastic medicine, medical historian, pharmaceutical historian and literary scholar, for their advice in interpreting the results.

\section{References}

1. (2003) Unschuld PU: Was ist Medizin? München: CH Beck.

2. Benedum J, Loew D, Schilcher H (2005) Arzneipflanzen in der Traditionellen Medizin. Kooperation Phytopharmaka (Eds). ( $4^{\text {th }}$ edn). Bonn: Kooperation Phytopharmaka Germany.

3. Mayer JG, Uehleke B, Daum K (2013) Das große Buch der Klosterheilkunde. München: ZS Verlag Xaver Sandmann Germany.

4. Wies EW (1992) Capitulare de villis et curtis imperialibus. Verordnung über die Krongüter und Reichshöfe und die Geheimisse des Kräutergartens Karls des Großen. Aachen: Einhard Germany.

5. Beer AM (2020) Phytotherapie zu Zeiten der Pest. Z Phytother 41(20): $1-4$
6. Beer AM, Uehleke B, Wiebelitz KR (2013) The history of inpatient care in German departments focussing on natural healing. Review article. Evid Based Complementary Altern Med 11: 521879.

7. Heyll U, Wasser, Fasten, Luft, Licht (2006) Die Geschichte der Naturheilkunde in Deutschland. Frankfurt/New York: Campus.

8. Weiss RF, Finkelmann V (1997) Lehrbuch der Phytotherapie. ( $8^{\text {th }}$ edn). Stuttgart: Hippokrates.

9. Dingermann Th, Loew D (2003) Phytopharmakologie. Experimentelle und klinische Pharmakologie pflanzlicher Arzneimittel. Stuttgart: Wissenschaftliche Verlagsgesellschaft: 1-5.

10.https://www.wiwi.uni-due.de/forschung/publikationen/ibesdiskussionsbeitraege/

11. Beer AM, Schilcher H, Loew D (2013) Phytotherapie in Not? Die derzeitige Lage in Deutschland. Dtsch Apoth Ztg 153(34): 54-59.

12. (2015) (Muster-)Weiterbildungsordnung. Bundesärztekammer: 1-204.

13. Beer AM (2020) Trotz Covid-19: 15 Ärztinnen und Ärzte erhalten Zertifikat "Phytotherapie für Ärzte”. Z Phytother 41: 197. 